\title{
High Expression of Cyclin DI is an Independent Marker for Favorable Prognosis in Middle Eastern Breast Cancer
}

\author{
Abdul K Siraj ${ }^{1, *}$ \\ Sandeep Kumar Parvathareddy ${ }^{\prime, *}$ \\ Padmanaban Annaiyappanaidu' \\ Saeeda O Ahmed' \\ Nabil Siraj' \\ Asma Tulbah ${ }^{2}$ \\ Fouad Al-Dayel ${ }^{2}$ \\ Dahish Ajarim ${ }^{3}$ \\ Khawla S Al-Kuraya (iD) \\ 'Human Cancer Genomic Research, King \\ Faisal Specialist Hospital and Research \\ Center, Riyadh, Saudi Arabia; \\ ${ }^{2}$ Department of Pathology, King Faisal \\ Specialist Hospital and Research Centre, \\ Riyadh, Saudi Arabia; ${ }^{3}$ Department of \\ Oncology, King Faisal Specialist Hospital \\ and Research Centre, Riyadh, II2II, \\ Saudi Arabia
}

*These authors contributed equally to this work
Correspondence: Khawla S Al-Kuraya Human Cancer Genomic Research, King Faisal Specialist Hospital and Research

Center, MBC\#98-16, P.O. Box 3354,

Riyadh, II2II, Saudi Arabia

Tel +966 I-205-5I67

Fax +966 I-205-5I70

Email kkuraya@kfshrc.edu.sa
Purpose: The cyclin D1 protein regulates cell cycle progression which is mediated by its interactions with cyclin-dependent kinases. Over-expression of cyclin D1 has been observed in several human cancers. This study was conducted to evaluate cyclin D1 expression in a large cohort of Middle Eastern breast cancers and determine its prognostic significance.

Patients and Methods: Cyclin D1 expression was assessed immunohistochemically and its association with clinico-pathological parameters was analyzed in 1003 breast cancer patients.

Results: Cyclin D1 was over-expressed in 59.4\% (596/1003) of cases and significantly associated with a subset of breast cancers having favorable prognostic features, such as low grade $(p<0.0001)$, low stage $(p=0.0276)$, estrogen receptor $(p<0.0001)$ and progesterone receptor positive $(\mathrm{p}<0.0001)$ tumors. An inverse association was found with triple negative breast cancers $(\mathrm{p}<0.0001)$. More importantly, cyclin D1 expression was an independent predictor of favorable overall survival in our cohort (hazard ratio $=0.70 ; 95 \%$ confidence interval $=0.50-0.98 ; \mathrm{p}=0.0395)$. Also, tumors that highly expressed cyclin D1 had a longer recurrence-free survival. However, this significant association was seen only in univariate analysis. We also found cyclin D1 to be associated with phospho-Rb in luminal subtype of breast cancer and co-expression of both these markers was an independent predictor of luminal A breast cancer.

Conclusion: Our results reinforced the role of cyclin D1 in breast cancer pathology and revealed its expression as a valuable independent prognostic indicator for breast cancer from Middle Eastern ethnicity.

Keywords: cyclin D1, breast cancer, prognosis, immunohistochemistry

\section{Introduction}

Breast cancer (BC) is known to be a molecularly heterogeneous cancer. ${ }^{1}$ It is the second most frequent cancer worldwide. ${ }^{2}$ In Saudi Arabia, breast cancer is the most prevalent cancer affecting women and usually presents at an advanced stage and younger median age. ${ }^{3-5}$ Therefore, identifying prognostic molecular marker for BC in Middle Eastern ethnicity is of great interest to predict prognosis and therapeutic response in this population.

Cyclin D1 (CCND1) gene, located on chromosome 11q13, encodes an important cell cycle G1 regulation protein, cyclin D1. ${ }^{6}$ The cyclin D1 protein regulates cell cycle progression, which is mediated by its interactions with cyclin-dependent kinases $(\mathrm{CDK} 4,6)$. The main role of cyclin 
D1/CDK-dependent pathway is to initiate phosphorylation of retinoblastoma protein and relieve histone deacetylase-binding, allowing cells to progress from G1 phase to S phase. ${ }^{7}$ Cyclin D1 also has CDK independent functions and could activate estrogen receptor (ER)-mediated transcription, independent of estrogen, which might modify the estrogen response. ${ }^{8}$ Currently, new functions have been described for CCND1, including the inhibition of mitochondrial metabolism, controlling the activity of transcription factors by recruitment of chromatin remodeling proteins, control of DNA damage by repair complexes and upregulation of noncoding sequences. ${ }^{9,10}$

Over-expression of cyclin D1 has been observed in several human cancers. ${ }^{11-15}$ This over-expression in tumors can be explained by multiple mechanisms, such as chromosomal translocation, gene amplification, polymorphism, post-transcriptional regulation of micro-RNA and post-translational mechanisms such as altered nuclear export and proteolysis. ${ }^{16}$

We have previously shown $C C N D 1$ amplification in the range of $15-20 \%^{5,17}$ in primary Middle Eastern and European breast cancer. Several other studies have shown a similarly low percentage of $C C N D 1$ amplification, ${ }^{12,18-20}$ despite the reported frequent over-expression of cyclin D1 protein in primary $\mathrm{BC},{ }^{11,12,18,21,22}$ implying that elevated expression of cyclin D1 is not always secondary to gene amplification in breast cancer. However, the prognostic value of cyclin D1 overexpression is controversial, with very limited data about its expression in breast cancer from this population. While several studies have reported cyclin D1 expression to be a favorable prognostic marker, ${ }^{12,22,23}$ other studies found it to be unfavorable ${ }^{24-26}$ in unselected BC. Some studies have reported the favorable prognosis only in ER positive BC. ${ }^{27,28}$ Disparities between studies can be partly explained by smaller sample size, mixed tumor analysis (ER positive/negative) and differences in applied methodologies, such as mRNA expression, gene amplification and protein expression.

To understand the contribution of cyclin D1 to tumor progression, a detailed analysis of its expression in Middle Eastern BC must be explored. Therefore, we conducted this study on a large cohort of unselected Middle Eastern BC from a single institute to evaluate the expression of cyclin D1 protein and its correlation with clinico-pathological markers as well as the effect of its expression on overall survival and recurrence-free survival.

\section{Patients and Methods}

\section{Patient Samples and Data Collection}

One thousand and nine patients with breast cancer diagnosed between 1990 and 2011 at King Faisal Specialist Hospital and Research Centre (KFSHRC) were included in the study. Detailed clinico-pathological data, including follow-up data, were noted from case records and have been summarized in Table 1. 2019 World Health Organization (WHO) classification of breast tumors was used to classify the histologic subtype of each breast tumor sample. Overall survival was defined as the length of time from the date of diagnosis, in which patients diagnosed with the disease are still alive. Recurrence-free survival is defined as the length of time after primary treatment for a cancer ends that the patient survives without any signs or symptoms of that cancer. The Institutional Review Board of King Faisal Specialist Hospital and Research Centre provided ethical approval for the current study. The Research Advisory Council (RAC) granted a waiver of informed consent for use of retrospective patient case data under project RAC\# 2140 008. This study was conducted in accordance with the Declaration of Helsinki.

\section{Tissue Microarray (TMA) Construction}

TMA construction was performed as described earlier. ${ }^{29}$ Briefly, tissue cylinders with a diameter of $0.6 \mathrm{~mm}$ were punched from representative tumor regions of each donor tissue block and brought into the recipient paraffin block using a modified semi-automatic robotic precision instrument (Beecher Instruments, Woodland, WI). Two cores of breast cancer were arrayed from each case.

\section{Immunohistochemistry (IHC) Staining and Evaluation}

Standard protocol was followed for IHC staining, as described previously. ${ }^{29}$ Briefly, for antigen retrieval, Dako (Dako Denmark A/S, Glostrup, Denmark) Target Retrieval Solution pH 9.0 (Catalog number S2368) was used, and the slides were placed in Pascal pressure cooker at $120^{\circ} \mathrm{C}$ for 10 minutes. Primary antibody against cyclin D1 (EP12, 1:200 dilution, pH 9.0, Dako, Carpinteria, CA) and phospho-Rb (Ser 807/ 811, 1:100 dilution, $\mathrm{pH}$ 9.0, Cell Signaling Technology, Danvers, MA, USA) was used. The Dako Envision Plus System kit was used as the secondary detection system with 3, 30-diaminobenzidine as chromogen. All slides were counterstained with hematoxylin, dehydrated, cleared and mounted. Negative controls included omission of the primary antibody. 
Table I Clinico-Pathological Variables for the Patient Cohort $(n=1009)$

\begin{tabular}{|c|c|}
\hline Clinico-Pathological Variables & n (\%) \\
\hline \multicolumn{2}{|l|}{ Age (years) } \\
\hline$\leq 50$ & $686(68.0)$ \\
\hline$>50$ & $323(32.0)$ \\
\hline Median & 45.0 \\
\hline Range(IQR) & $39.0-54.0$ \\
\hline \multicolumn{2}{|l|}{ Histological type } \\
\hline Infiltrating Ductal carcinoma & $913(90.5)$ \\
\hline Infiltrating Lobular carcinoma & $44(4.4)$ \\
\hline Mucinous carcinoma & $16(1.6)$ \\
\hline Others & $36(3.5)$ \\
\hline \multicolumn{2}{|l|}{ TNM Stage } \\
\hline I & $91(9.0)$ \\
\hline II & $40 \mathrm{I}(39.7)$ \\
\hline III & $379(37.6)$ \\
\hline IV & $91(9.0)$ \\
\hline Unknown & $47(4.7)$ \\
\hline \multicolumn{2}{|l|}{ Histologic Grade } \\
\hline Well differentiated & $77(7.6)$ \\
\hline Moderately differentiated & $514(50.9)$ \\
\hline Poorly differentiated & $405(40.2)$ \\
\hline Unknown & $13(1.3)$ \\
\hline \multicolumn{2}{|l|}{ Estrogen Receptor } \\
\hline Positive & $662(65.6)$ \\
\hline Negative & $346(34.3)$ \\
\hline Unknown & I $(0.1)$ \\
\hline \multicolumn{2}{|l|}{ Progesterone Receptor } \\
\hline Positive & $579(57.4)$ \\
\hline Negative & $426(42.2)$ \\
\hline Unknown & $4(0.4)$ \\
\hline \multicolumn{2}{|l|}{ Her-2 neu } \\
\hline Positive & $379(37.6)$ \\
\hline Negative & $628(62.2)$ \\
\hline Unknown & $2(0.2)$ \\
\hline \multicolumn{2}{|l|}{ Triple Negative Breast Cancer } \\
\hline Yes & $149(14.8)$ \\
\hline No & $852(84.4)$ \\
\hline Unknown & $8(0.8)$ \\
\hline \multicolumn{2}{|l|}{ Survival Duration (in months) } \\
\hline Median & 48.0 \\
\hline Range(IQR) & $26.0-74.0$ \\
\hline
\end{tabular}

Abbreviation: IQR, inter-quartile range.

Normal tissues from different organ systems were also included in the TMA to serve as control. Only fresh cut slides were stained simultaneously to minimize the influence of slide aging and maximize reproducibility of the experiment.

Both nuclear and cytoplasmic stainings of tumor cells were noted (Supplementary Figure 1). However, only nuclear staining was considered for scoring. Scoring of cyclin D1 was performed as described previously, ${ }^{30}$ using $\mathrm{H}$ score. Briefly, each TMA spot was assigned an intensity score from 0 to 3 (I0, I1-3) and the proportion of the tumor staining for that intensity was recorded from a range of $0-100$ (P0, P1-3). P0 and P1-3 signify the proportion of positively stained cells corresponding to the respective intensity score (I0, I1-3) (ie, P1 signifies the proportion of tumor cells which show intensity I1, P2 signifies the proportion of tumor cells which show intensity I2, and so on. Supplementary Figure 2). A final $\mathrm{H}$ score (range 0-300) was obtained by adding the sum of scores obtained for each intensity (I) and proportion (P) of area stained $(\mathrm{H}$ score $=\mathrm{I} 1 \mathrm{XP} 1+\mathrm{I} 2 \mathrm{XP} 2+\mathrm{I} 3 \mathrm{XP} 3)$. Two scores per tumor were analyzed in order to minimize the number of missing/un-interpretable spots. However, the higher of the two scores was used as the final score. $\mathrm{X}$-tile plots were constructed for assessment of biomarker and optimization of cut-off points based on outcome, as has been described earlier. ${ }^{31}$ Based on X-tile plots, BC cases were classified into two subgroups: those with $\mathrm{H}$ score $\leq 40$ were defined as low expression of cyclin D1 and those with $\mathrm{H}$ score $>40$ were defined as overexpression.

Phospho-Rb was scored as described previously. ${ }^{32}$ Briefly, the proportion of positively stained cells were calculated as a percentage for each core and the scores were averaged across two tissue cores from the same tumor to yield a single percent staining score representing each cancer patient. For the purpose of statistical analysis, the scores were dichotomised. Cases showing an expression level of $\geq 25 \%$ were classified as over-expression for phospho- $\mathrm{Rb}$ and those with less than $25 \%$ as low expression. Staining and scoring of ER, PR and Her-2 neu was performed as described previously. ${ }^{33}$

\section{Statistical Analysis}

The associations between clinico-pathological variables and protein expression was performed using contingency table analysis and chi-square tests. Mantel-Cox Log rank test was used to evaluate overall survival and recurrencefree survival. Survival curves were generated using the 
Kaplan-Meier method. Cox proportional hazards regression model was used for multivariate analysis. Two-sided tests were used for statistical analyses with a limit of significance defined as $\mathrm{p}$ value $<0.05$. Data analysis was performed using the JMP11.0 (SAS Institute, Inc., Cary, NC) software package.

\section{Results}

\section{Patient Characteristics}

The median age of the study population was 45 years (range: 14-94 years). Infiltrating ductal carcinoma was the most common histologic subtype, accounting for $90.5 \%(913 / 1009)$ of BC. The majority of the patients had moderately to poorly differentiated tumors $(91.1 \%$, $919 / 1009)$ and $9.0 \%(91 / 1009)$ presented with distant metastasis at diagnosis. 65.6\% (662/1009) of tumors were ER positive, 57.4\% (579/1009) were progesterone receptor (PR) positive and 37.6\% (379/1009) were Her-2 neu positive. $14.8 \%(149 / 1009)$ of tumors were triple negative breast cancers (Table 1).

\section{Cyclin DI Expression in Breast Cancer and Its Clinico-Pathological Associations}

Cyclin D1 protein expression was analyzed immunohistochemically in 1009 BC samples. However, immunohistochemistry data were interpretable in 1003 samples and hence were included for further analysis. Nuclear overexpression of cyclin D1 was noted in 59.4\% (596/1003) of cases (Figure 1). Cyclin D1 over-expression was found to be associated with favorable clinico-pathological characteristics, such as low-grade tumors $(\mathrm{p}<0.0001)$, smaller tumor size $(p=0.0013)$, stage I tumors $(p=0.0276)$, ER positive $(\mathrm{p}<0.0001)$ and PR positive tumors $(\mathrm{p}<0.0001)$. Interestingly, an inverse association was noted between cyclin D1 over-expression and triple negative breast cancers $(\mathrm{p}<0.0001)$ (Table 2).

\section{Cyclin DI Expression and Clinical Outcome}

Nuclear cyclin D1 over-expression was found to have a favorable impact on overall survival $(\mathrm{p}=0.0011$, Table 2, Figure 2A). On multivariate analysis, cyclin D1 was an independent prognostic indicator of overall survival $(\mathrm{HR}=0.70,95 \% \mathrm{CI}=0.50-0.98, \mathrm{p}=0.0395)$ (Table 3). Patients with cyclin D1 over-expression were also found to have a favorable recurrence-free survival ( $p=0.0327$, Table 2, Figure 2B). However, recurrencefree survival was not significant on multivariate analysis $(\mathrm{HR}=0.85,95 \% \mathrm{CI}=0.66-1.13, \mathrm{p}=0.2682)($ Table 3$)$.

\section{Cyclin DI Expression in Different Subgroups of Breast Cancer}

Prognosis of breast cancer varies in different molecular subgroups of BC. Since we found a significant association between cyclin D1 expression and clinical outcome in the entire cohort, we analyzed the expression and clinical outcome in three molecular subgroups of $\mathrm{BC}$ : luminal, hormone receptor-negative/HER2-positive and

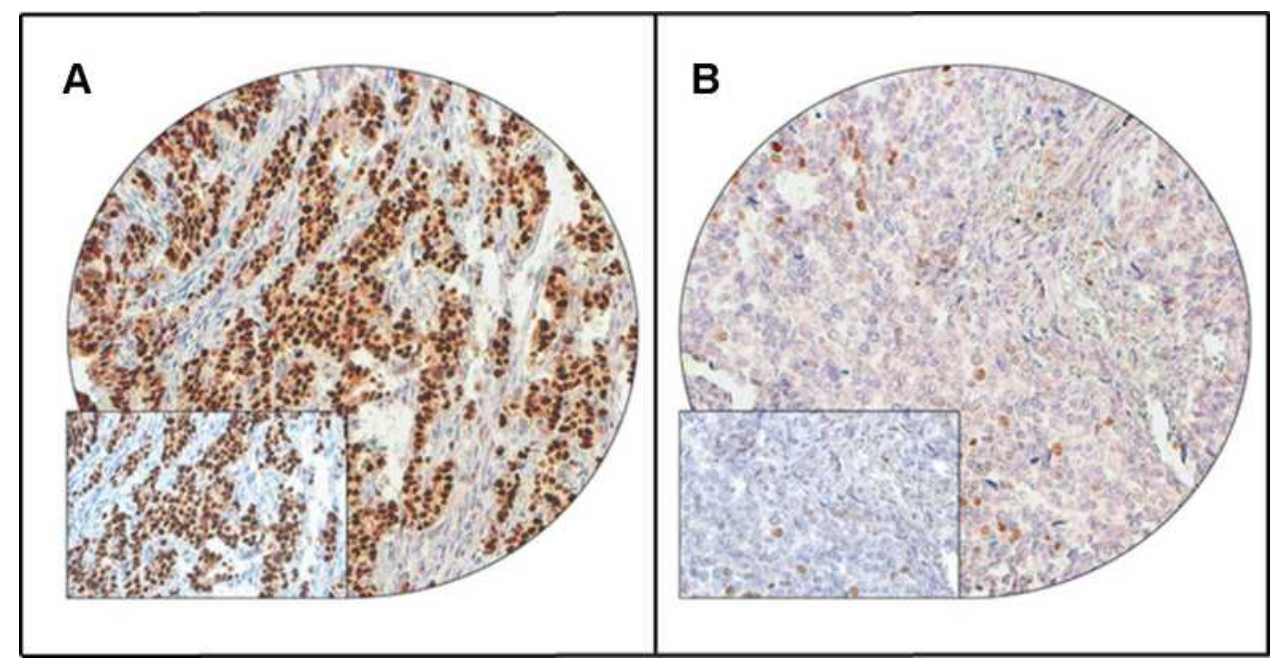

Figure I Cyclin DI immunohistochemical staining in Breast cancer TMA. Representative examples of tumors showing (A) high expression and (B) low expression (right panel) of cyclin DI. (20 X/0.70 objective on an Olympus BX 51 microscope. (Olympus America Inc, Center Valley, PA, USA) with the inset showing a $40 \times 0.85$ aperture magnified view of the same TMA spot). 
Table 2 Correlation of Cyclin DI Protein Expression with Clinico-Pathological Parameters in Breast Cancer

\begin{tabular}{|c|c|c|c|c|c|c|c|}
\hline \multirow[t]{2}{*}{ Clinico-Pathological Variables } & \multicolumn{2}{|c|}{ Total } & \multicolumn{2}{|c|}{ Cyclin DI High Expression } & \multicolumn{2}{|c|}{ Cyclin DI Low Expression } & \multirow[t]{2}{*}{ p value } \\
\hline & $\mathbf{N}$ & $\%$ & $\mathbf{N}$ & $\%$ & $\mathbf{N}$ & $\%$ & \\
\hline Total Number of Cases & 1003 & & 596 & 59.4 & 407 & 40.6 & \\
\hline \multicolumn{8}{|l|}{ Age Groups } \\
\hline$\leq 50$ & 681 & 67.9 & 399 & 58.6 & 282 & 41.4 & 0.4396 \\
\hline$>50$ & 322 & 32.1 & 197 & 61.2 & 125 & 38.8 & \\
\hline \multicolumn{8}{|l|}{ Histology } \\
\hline Infiltrating Ductal Carcinoma & 910 & 94.0 & 544 & 59.8 & 366 & 40.2 & 0.1741 \\
\hline Infiltrating Lobular Carcinoma & 42 & 4.3 & 24 & 57.1 & 18 & 42.9 & \\
\hline Mucinous Carcinoma & 16 & 1.7 & 13 & 81.2 & 3 & 18.8 & \\
\hline \multicolumn{8}{|l|}{ Histological Grade } \\
\hline Well differentiated & 76 & 7.7 & 55 & 72.4 & 21 & 27.6 & $<0.000 I^{*}$ \\
\hline Moderately differentiated & 511 & 51.5 & 357 & 69.9 & 154 & 30.1 & \\
\hline Poorly differentiated & 404 & 40.8 & 177 & 43.8 & 227 & 56.2 & \\
\hline \multicolumn{8}{|l|}{ pT } \\
\hline TI & 214 & 22.2 & 148 & 69.2 & 66 & 30.8 & $0.0013^{*}$ \\
\hline $\mathrm{T} 2$ & 484 & 50.3 & 289 & 59.7 & 195 & 40.3 & \\
\hline T3 & 143 & 14.8 & 70 & 49.0 & 73 & 51.0 & \\
\hline T4 & 122 & 12.7 & 68 & 55.7 & 54 & 44.3 & \\
\hline \multicolumn{8}{|l|}{$\mathrm{pN}$} \\
\hline No & 306 & 33.1 & 181 & 59.1 & 125 & 40.9 & 0.3338 \\
\hline $\mathrm{NI}$ & 298 & 32.3 & 172 & 57.7 & 126 & 42.3 & \\
\hline N2 & 192 & 20.8 & 123 & 64.1 & 69 & 35.9 & \\
\hline N3 & 127 & 13.8 & 69 & 54.3 & 58 & 45.7 & \\
\hline \multicolumn{8}{|l|}{ pM } \\
\hline Mo & 913 & 91.0 & 550 & 60.2 & 363 & 39.8 & 0.0948 \\
\hline MI & 90 & 9.0 & 46 & 51.1 & 44 & 48.9 & \\
\hline \multicolumn{8}{|l|}{ Tumor Stage } \\
\hline I & 91 & 9.5 & 65 & 71.4 & 26 & 28.6 & $0.0276^{*}$ \\
\hline II & 398 & 41.6 & 241 & 60.5 & 157 & 39.5 & \\
\hline III & 377 & 39.5 & 216 & 57.3 & 161 & 42.7 & \\
\hline IV & 90 & 9.4 & 46 & 51.1 & 44 & 48.9 & \\
\hline \multicolumn{8}{|l|}{ Estrogen receptor } \\
\hline Positive & 656 & 65.5 & 476 & 72.6 & 180 & 27.4 & $<0.000 I^{*}$ \\
\hline Negative & 346 & 34.5 & 120 & 34.7 & 226 & 65.3 & \\
\hline \multicolumn{8}{|l|}{ Progesterone receptor } \\
\hline Positive & 574 & 57.5 & 422 & 73.5 & 152 & 26.5 & $<0.0001 *$ \\
\hline Negative & 425 & 42.5 & 171 & 40.2 & 254 & 59.8 & \\
\hline \multicolumn{8}{|l|}{ Her-2 neu } \\
\hline Positive & 377 & 37.6 & 232 & 61.5 & 145 & 38.5 & 0.2796 \\
\hline Negative & 625 & 62.4 & 363 & 58.1 & 262 & 41.9 & \\
\hline
\end{tabular}


Table 2 (Continued).

\begin{tabular}{|c|c|c|c|c|c|c|c|}
\hline \multirow[t]{2}{*}{ Clinico-Pathological Variables } & \multicolumn{2}{|c|}{ Total } & \multicolumn{2}{|c|}{ Cyclin DI High Expression } & \multicolumn{2}{|c|}{ Cyclin DI Low Expression } & \multirow[t]{2}{*}{ p value } \\
\hline & $\mathbf{N}$ & $\%$ & $\mathbf{N}$ & $\%$ & $\mathbf{N}$ & $\%$ & \\
\hline \multicolumn{8}{|l|}{ Triple Negative Breast Cancer } \\
\hline Yes & 149 & 15.0 & 38 & 25.5 & III & 74.5 & $<0.0001 *$ \\
\hline No & 847 & 85.0 & 554 & 65.4 & 293 & 34.6 & \\
\hline \multicolumn{8}{|l|}{ Phospho-Rb } \\
\hline High & 298 & 31.0 & 189 & 63.4 & 109 & 36.6 & 0.1011 \\
\hline Low & 664 & 69.0 & 384 & 57.8 & 280 & 42.2 & \\
\hline Overall Survival & & & & 83.3 & & 75.6 & $0.0011 *$ \\
\hline Recurrence-free survival & & & & 78.8 & & 71.6 & $0.0327^{*}$ \\
\hline
\end{tabular}

Note: *Significant $\mathrm{p}$ value.

triple-negative breast cancer. Cyclin D1 over-expression was noted in $70.1 \%(500 / 713)$ of luminal, $40.2 \%$ (53/ 132) of hormone receptor-negative/HER2- positive and $25.5 \%(38 / 149)$ of triple-negative breast cancer cases. We found a significant association between cyclin D1 expression and phospho-retinoblastoma $(\mathrm{Rb})$ expression in luminal subgroup $(p=0.0041)$ but not in the other two subgroups of BC. Cyclin D1 over-expression was significantly associated with good overall survival in only hormone receptor-negative/HER2- positive BC ( $p$ $=0.0262$ ), whereas recurrence-free survival was not significant in any of the three subgroups analyzed (Supplementary Tables 1-3, Supplementary Figure 3).

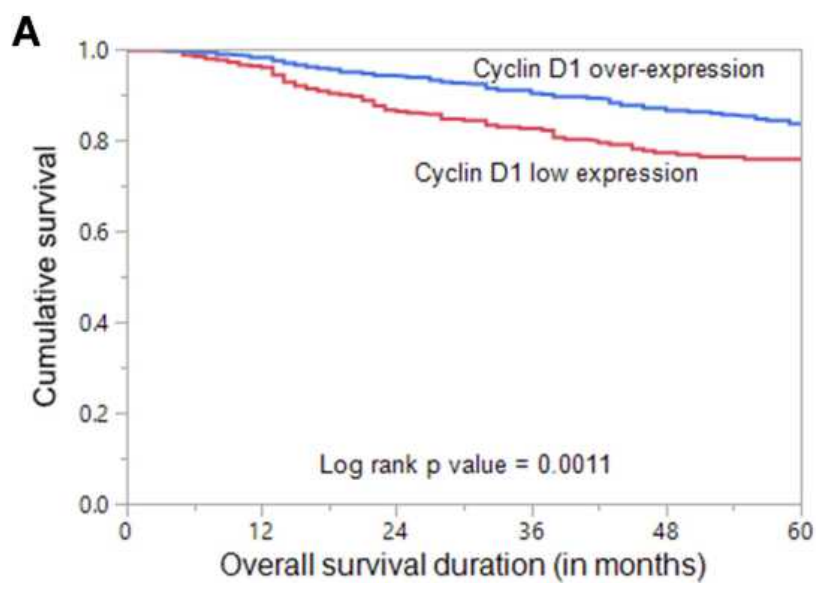

\section{Cyclin DI and Phospho-Rb Co-Expression Predicts Luminal Subtype of Breast Cancer}

Since we found a significant association between cyclin D1 and phospho- $\mathrm{Rb}$ expression in luminal $\mathrm{BC}$, we sought to determine if cyclin D1 and phospho-Rb co-expression could predict luminal subtype of BC. In multivariate logistic regression analysis, combined cyclin D1 and phospho-Rb overexpression was indeed a predictor of luminal BC (Odds ratio $=3.68 ; 95 \%$ confidence interval $=2.08-6.51 ; \mathrm{p}<$ 0.0001). On further stratification of the luminal subtype, we found that the cyclin D1 and phospho-Rb overexpression was a predictor of luminal A subtype (Odds ratio = 1.96; 95\%

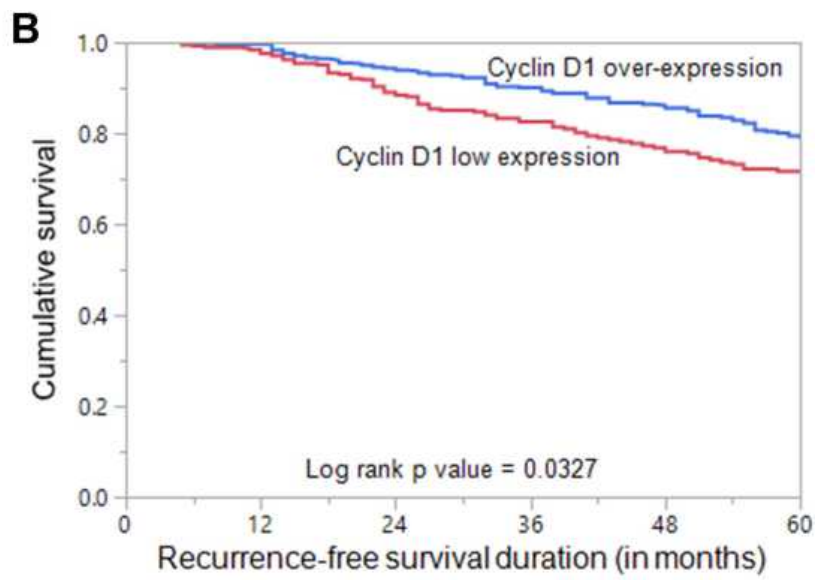

Figure 2 Survival Analysis of Cyclin DI protein expression in Breast cancer. (A) Kaplan Meier survival plot showing statistically significant good overall survival in cyclin DI over-expression $(\mathrm{H}$ score $>40)$ cases compared to cyclin DI low expression $(\mathrm{H}$ score $\leq 40)(\mathrm{p}=0.00 \mathrm{II})$ (B) Kaplan Meier survival plot showing statistically significant good recurrence-free survival for cyclin DI over-expression $(p=0.0327)$. 
Table 3 Univariate and Multivariate Analysis of Clinico-Pathological Variables and Cyclin DI Expression Using Cox Proportional Hazard Model for Overall Survival and Recurrence-Free Survival

\begin{tabular}{|c|c|c|c|c|c|c|c|c|}
\hline \multirow{3}{*}{$\begin{array}{l}\text { Clinico- } \\
\text { Pathological } \\
\text { Variables }\end{array}$} & \multicolumn{4}{|c|}{ Overall Survival } & \multicolumn{4}{|c|}{ Recurrence-Free Survival } \\
\hline & \multicolumn{2}{|c|}{ Univariate } & \multicolumn{2}{|c|}{ Multivariate } & \multicolumn{2}{|c|}{ Univariate } & \multicolumn{2}{|c|}{ Multivariate } \\
\hline & $\begin{array}{l}\text { Hazard } \\
\text { Ratio } \\
(95 \% \mathrm{Cl})\end{array}$ & p-value & $\begin{array}{l}\text { Hazard Ratio } \\
(95 \% \mathrm{Cl})\end{array}$ & p-value & $\begin{array}{l}\text { Hazard Ratio } \\
(95 \% \mathrm{Cl})\end{array}$ & p-value & $\begin{array}{l}\text { Hazard Ratio } \\
(95 \% \mathrm{CI})\end{array}$ & p-value \\
\hline $\begin{array}{l}\text { Age (years) }>50 \\
(v s \leq 50)\end{array}$ & $\begin{array}{l}0.98 \\
(0.70-1.34)\end{array}$ & 0.8876 & $\begin{array}{l}0.90 \\
(0.63-1.26)\end{array}$ & 0.5519 & $\begin{array}{l}0.93 \\
(0.70-1.2 I)\end{array}$ & 0.5961 & $\begin{array}{l}0.87 \\
(0.65-1.15)\end{array}$ & 0.3421 \\
\hline $\begin{array}{l}\text { Histology IDC } \\
\text { (vs others) }\end{array}$ & $\begin{array}{l}0.45 \\
(0.20-0.86)\end{array}$ & $0.0276 *$ & $\begin{array}{l}0.39 \\
(0.16-0.95)\end{array}$ & $0.0383 *$ & $\begin{array}{l}0.38 \\
(0.19-0.68)\end{array}$ & $0.0027^{*}$ & $\begin{array}{l}0.37 \\
(0.19-0.72)\end{array}$ & $0.0034 *$ \\
\hline $\begin{array}{l}\text { Grade } \\
3 \text { (vs I-2) }\end{array}$ & $\begin{array}{l}1.53 \\
(1.14-2.06)\end{array}$ & $0.0048 *$ & $\begin{array}{l}1.30 \\
(0.93-1.82)\end{array}$ & 0.1239 & $\begin{array}{l}1.53 \\
(1.20-1.96)\end{array}$ & $0.0006 *$ & $\begin{array}{l}1.44 \\
(1.11-1.88)\end{array}$ & $0.0068 *$ \\
\hline $\begin{array}{l}\text { Lymph node } \\
\text { metastasis NI-3 } \\
\text { (vs N0) }\end{array}$ & $\begin{array}{l}2.91 \\
(1.94-4.52)\end{array}$ & $<0.0001^{*}$ & $\begin{array}{l}1.71 \\
(1.04-2.8 I)\end{array}$ & $0.0342 *$ & $\begin{array}{l}1.91 \\
(1.44-2.59)\end{array}$ & $<0.0001 *$ & $\begin{array}{l}1.20 \\
(0.82-1.74)\end{array}$ & 0.3474 \\
\hline $\begin{array}{l}\text { Distant metastasis } \\
\text { MI (vs M0) }\end{array}$ & $\begin{array}{l}6.70 \\
(4.75-9.30)\end{array}$ & $<0.0001 *$ & $\begin{array}{l}3.12 \\
(2.04-4.70)\end{array}$ & $<0.0001$ & $\begin{array}{l}1.65 \\
(0.99-2.56)\end{array}$ & 0.0526 & $\begin{array}{l}0.96 \\
(0.55-\mid .58)\end{array}$ & 0.8918 \\
\hline Stage III-IV (vs I-II) & $\begin{array}{l}4.79 \\
(3.39-6.91)\end{array}$ & $<0.0001 *$ & $\begin{array}{l}2.74 \\
(I .78-4.3 I)\end{array}$ & $<0.0001 *$ & $\begin{array}{l}2.57 \\
(2.00-3.33)\end{array}$ & $<0.0001 *$ & $\begin{array}{l}2.37 \\
(1.72-3.32)\end{array}$ & $<0.000 I^{*}$ \\
\hline TNBC Yes (vs No) & $\begin{array}{l}1.87 \\
(1.28-2.66)\end{array}$ & $0.0007^{*}$ & $\begin{array}{l}1.25 \\
(0.80-1.92)\end{array}$ & 0.3103 & $\begin{array}{l}1.35 \\
(0.94-1.87)\end{array}$ & 0.0882 & $\begin{array}{l}1.03 \\
(0.69-1.50)\end{array}$ & 0.8913 \\
\hline $\begin{array}{l}\text { Cyclin DIHigh } \\
\text { (vs Low) }\end{array}$ & $\begin{array}{l}0.62 \\
(0.46-0.83)\end{array}$ & $0.0013^{*}$ & $\begin{array}{l}0.70 \\
(0.50-0.98)\end{array}$ & $0.0395^{*}$ & $\begin{array}{l}0.76 \\
(0.60-0.98)\end{array}$ & $0.0338^{*}$ & $\begin{array}{l}0.85 \\
(0.66-1.13)\end{array}$ & 0.2682 \\
\hline
\end{tabular}

Note: *Significant $\mathrm{p}$ value.

confidence interval $=1.35-2.85 ; \mathrm{p}=0.0004)$ but not luminal B subtype of breast cancer (Odds ratio $=1.13 ; 95 \%$ confidence interval $=0.79-1.62 ; \mathrm{p}=0.5071)($ Table 4$)$.

\section{Discussion}

It has been widely accepted that cyclin D1 is involved in breast carcinogenesis, through enhancement of cell proliferation and differentiation, as well as shortening the G1/S transition and interaction with ER. ${ }^{34,35}$ Our present study showed that cyclin D1 expression was upregulated in Middle Eastern breast cancer tissues. Overexpression of cyclin D1 by immunohistochemistry has been reported in $35-80 \%$ of breast cancers, ${ }^{11,12,21,22}$ in line with our results. In our series of more than 1000 Middle Eastern BC, 59.4\% (596/1003) of cases showed overexpression of cyclin D1. We observed a positive correlation between low expression of cyclin D1 and triple-negative breast cancer, which is a highly aggressive subtype of breast cancer, whereas overexpression of cyclin D1 was significantly associated with lower histological grade and stage. Similar associations have been reported in previous studies. ${ }^{12,21,22,36}$ One of the proposed explanations could be attributed to the interaction between cyclin D1, histone acetylase and $\mathrm{Rb}$ which could potentially cause cell cycle exit and induce growth arrest. ${ }^{37,38}$ As expected, there is a strong and statistically significant association between cyclin D1 protein overexpression and ER expression, which is in agreement with previous studies. ${ }^{12,18,20,22}$

There is no clear consensus regarding the predictive and prognostic values of cyclin D1 overexpression in breast cancer. $^{23,24,39}$ Our series confirms that cyclin D1 overexpression has a favorable impact on overall survival $(\mathrm{HR}=0.70$, $95 \% \mathrm{CI}=0.50-0.98, \mathrm{p}=0.0395$ ), which stands true even in multivariate analysis. In addition, tumors that highly expressed cyclin D1 tended to have longer recurrence-free survival in our cohort. However, this significant association was seen only in univariate analysis. A recent study has also explored the impact 
Table 4 Multivariate Logistic Regression Analysis to Assess the Predictive Value of CyclinDI and Phospho-Rb Co-Expression for Luminal Breast Cancer

\begin{tabular}{|c|c|c|c|c|c|c|}
\hline \multirow[t]{2}{*}{ Clinico-Pathological Variables } & \multicolumn{2}{|c|}{$\begin{array}{c}\text { Luminal (A and B) Breast } \\
\text { Cancer }\end{array}$} & \multicolumn{2}{|c|}{ Luminal A Breast Cancer } & \multicolumn{2}{|c|}{$\begin{array}{c}\text { Luminal B Breast } \\
\text { Cancer }\end{array}$} \\
\hline & $\begin{array}{c}\text { Odds Ratio } \\
\text { (95\% Cl) }\end{array}$ & p-value & $\begin{array}{c}\text { Odds Ratio } \\
\text { (95\% Cl) }\end{array}$ & p-value & $\begin{array}{c}\text { Odds Ratio } \\
\text { (95\% Cl) }\end{array}$ & p-value \\
\hline Age (years) >50 (vs $\leq 50)$ & $1.51(1.06-2.15)$ & $0.0215^{*}$ & $1.25(0.90-1.73)$ & 0.1794 & I.I7 (0.87-I.57) & 0.2992 \\
\hline Histology IDC (vs others) & $2.06(1.00-4.28)$ & $0.0396 *$ & $2.30(1.34-3.95)$ & $0.0024 *$ & $0.7 \mid(0.4|-| .2 I)$ & 0.1996 \\
\hline Grade 3 (vs I-2) & $0.28(0.20-0.39)$ & $<0.0001 *$ & $0.26(0.19-0.37)$ & $<0.0001 *$ & $0.96(0.72-1.28)$ & 0.7722 \\
\hline Lymph node metastasis NI-3 (vs N0) & $1.32(0.88-1.99)$ & 0.1841 & I.II (0.75-I.64) & 0.6108 & $1.19(0.84-1.68)$ & 0.3277 \\
\hline Distant metastasis MI (vs M0) & $0.48(0.27-0.86)$ & 0.0140 & $0.45(0.22-0.91)$ & $0.0258 *$ & $0.87(0.50-1.5 \mathrm{I})$ & 0.6184 \\
\hline Stage III-IV (vs I-II) & $0.86(0.57-1.30)$ & 0.4847 & $1.15(0.78-1.68)$ & 0.4822 & $0.8 \mathrm{I}(0.57-1.14)$ & 0.2232 \\
\hline $\begin{array}{l}\text { Cyclin DI + phospho-Rb over- } \\
\text { expression Yes (vs No) }\end{array}$ & $3.68(2.08-6.5 I)$ & $<0.0001$ & $1.96(1.35-2.85)$ & $0.0004^{*}$ & $1.13(0.79-1.62)$ & $0.507 \mid$ \\
\hline
\end{tabular}

Note: *Significant $\mathrm{p}$ value.

of cyclin D1 expression on patient survival. They found that breast cancer patients with cyclin D1 alterations had improved prognosis when compared to patients without cyclin D1 alterations, which is similar to our results. ${ }^{40}$ In addition, other previous reports that have also shown overexpression of cyclin D1 to be a good prognostic factor, ${ }^{12,22,23}$ in concordance with our findings. A possible explanation for the favorable prognosis in our cohort could be the association of cyclin D1 with lowgrade tumors and ER positive tumors, which are known to have a lower breast cancer stem cell population and hence tend to have a better prognosis. $^{41}$

Since many studies have succeeded in finding a prognostic value for cyclin D1 overexpression in luminal (hormone receptor positive) $\mathrm{BC},{ }^{12,21,27,28,42}$ we sought to further explore the prognostic impact of cyclin D1 on hormone receptor-positive tumors. Upon analysis of prognosis in luminal tumors, which accounted for $71.1 \%(713 / 1003)$ of our cohort, no prognostic correlation was observed in this subset of $\mathrm{BC}$, which is inconsistent with previous studies, where favorable prognosis was seen in this subset of BC. ${ }^{27,28}$ These discrepancies might be partly explained by differing sample size, different antibodies used, prior treatment for BC or could be due to heterogeneity of breast cancer and reflect the role of different ethnicity in breast cancer biology. Previous studies have shown that cyclin $\mathrm{D}$ regulates cell cycle progression by phosphorylation of retinoblastoma $(\mathrm{Rb})$ protein. $^{43,44}$ Hence, we examined the expression of phospho-Rb and its association with cyclin D1. We found a significant association between cyclin D1 and
phospho-Rb in the luminal subgroup of breast cancer but not in the entire cohort. However, multivariate logistic regression analysis revealed that co-expression of cyclin D1 and phospho$\mathrm{Rb}$ was an independent predictor for luminal A subtype of BC. This indicates that cyclin D1 may be linked to cell cycle in luminal A breast cancer and its expression may be used as a predictor in this subgroup of BC. Indeed, a previous study has shown cyclin D1 to be associated with cell cycle activation in luminal BC. ${ }^{21}$ This predictive role of cyclin D1 and phospho$\mathrm{Rb}$ adds strength to the paper since analysing phospho- $\mathrm{Rb}$ by immunohistochemistry can be translated easily to the clinical setting.

Despite the strength of our study being the use of a clinically and histologically well-characterized large $\mathrm{BC}$ cohort from a unique ethnic population (Middle Eastern), there are few limitations. This is a retrospective, single centre study, where patients were enrolled over a long period of time, during which the surgical and therapeutic approaches may have changed.

\section{Conclusions}

In summary, our results demonstrate that cyclin D1 overexpression is frequent in our unselected large cohort of Middle Eastern BC. Our data have also shown that cyclin $\mathrm{D} 1$ overexpression is associated with a subset of $\mathrm{BC}$ having favorable prognostic features (ER positive, PR positive, low grade and low stage), and inversely correlated with aggressive TNBC, which might suggest that cyclin D1 plays 
different roles in different molecular subtypes of BC. More importantly, cyclin D1 expression is an independent predictive marker of favorable outcome in Middle Eastern BC. Overall, our results reinforce the role of cyclin D1 in BC pathology and reveal that co-expression of cyclin D1 and phospho-Rb can predict luminal A breast cancer, which could have important therapeutic implication for this subgroup of $\mathrm{BC}$.

\section{Ethics Approval and Consent to Participate}

The Institutional Review Board of King Faisal Specialist Hospital and Research Centre provided ethical approval for the current study. The Research Advisory Council (RAC) granted a waiver of informed consent for use of retrospective patient case data under project RAC\# 2140 008. All the methods were carried out in accordance with relevant guidelines and regulations.

\section{Acknowledgments}

The authors would like to thank Felisa DeVera for her technical assistance.

\section{Author Contributions}

A.K.S. designed the study and helped write the manuscript. S. K.P. performed the immunohistochemical experiments, analyzed the data and helped write the manuscript. P.A., S.O. A. and N.S. were involved in performing the experiments and helped write the manuscript. F.A. and A.T. provided the clinical resources, executed of the study and were involved in drafting the manuscript. D.A. provided the clinical resources, executed the study and was involved in drafting the manuscript. K.S.A. conceptualized and designed the study, supervised the study and drafted the manuscript. All authors made substantial contributions to conception and design, acquisition of data, or analysis and interpretation of data; took part in drafting the article or revising it critically for important intellectual content; agreed to submit to the current journal; gave final approval of the version to be published; and agree to be accountable for all aspects of the work.

\section{Funding}

The authors received no specific funding for this work.

\section{Disclosure}

The authors declare that they have no conflicts of interest for this work.

\section{References}

1. Stingl J, Caldas C. Molecular heterogeneity of breast carcinomas and the cancer stem cell hypothesis. Nat Rev Cancer. 2007;7 (10):791-799. doi:10.1038/nrc2212

2. Bray F, Ferlay J, Soerjomataram I, Siegel RL, Torre LA, Jemal A. Global cancer statistics 2018: GLOBOCAN estimates of incidence and mortality worldwide for 36 cancers in 185 countries. CA Cancer J Clin. 2018;68(6):394-424. doi:10.3322/caac.21492

3. Alrawaji A, Alshahrani Z, Alzahrani W, et al. Cancer incidence report Saudi Arabia 2015. In: Saudi Health Council, editor. Saudi Cancer Registry. Riyadh; 2018:34-35.

4. Al Tamimi DM, Shawarby MA, Ahmed A, Hassan AK, AlOdaini AA. Protein expression profile and prevalence pattern of the molecular classes of breast cancer-a Saudi population based study. BMC Cancer. 2010;10(1):223. doi:10.1186/14712407-10-223

5. Al-Kuraya K, Schraml P, Sheikh S, et al. Predominance of high-grade pathway in breast cancer development of Middle East women. Mod Pathol. 2005;18(7):891-897. doi:10.1038/modpathol.3800408

6. Inoue K, Fry EA. Aberrant expression of cyclin D1 in cancer. Sign Transduct Insights. 2015;4(STI):S30306. doi:10.4137/STI.S30306

7. Sherr CJ, Roberts JM. CDK inhibitors: positive and negative regulators of G1-phase progression. Genes Dev. 1999;13(12):1501-1512. doi:10.1101/gad.13.12.1501

8. Zwijsen RM, Wientjens E, Klompmaker R, van der Sman J, Bernards R, Michalides RJ. CDK-independent activation of estrogen receptor by cyclin D1. Cell. 1997;88(3):405-415. doi:10.1016/ S0092-8674(00)81879-6

9. Pestell RG. New roles of cyclin D1. Am J Pathol. 2013;183(1):3-9. doi:10.1016/j.ajpath.2013.03.001

10. Casimiro MC, Crosariol M, Loro E, et al. ChIP sequencing of cyclin D1 reveals a transcriptional role in chromosomal instability in mice. J Clin Invest. 2012;122(3):833-843. doi:10.1172/JCI60256

11. Mountzios G, Kotoula V, Kolliou G-A, et al. Cyclin D1 differential activation and its prognostic impact in patients with advanced breast cancer treated with trastuzumab. ESMO Open. 2019;4(2):e000441. doi:10.1136/esmoopen-2018-000441

12. Ortiz AB, Garcia D, Vicente Y, Palka M, Bellas C, Martin P. Prognostic significance of cyclin D1 protein expression and gene amplification in invasive breast carcinoma. PLoS One. 2017;12(11): e0188068. doi:10.1371/journal.pone. 0188068

13. Haddad AQ, Luo JH, Krabbe LM, et al. Prognostic value of tissuebased biomarker signature in clear cell renal cell carcinoma. BJU Int. 2017;119(5):741-747. doi:10.1111/bju.13776

14. Almangush A, Heikkinen I, Mäkitie AA, et al. Prognostic biomarkers for oral tongue squamous cell carcinoma: a systematic review and meta-analysis. Br J Cancer. 2017;117(6):856-866. doi:10.1038/ bjc. 2017.244

15. Li Y, Wei J, Xu C, Zhao Z, You T, Katoh M. Prognostic significance of cyclin D1 expression in colorectal cancer: a meta-analysis of observational studies. PLoS One. 2014;9(4):e94508. doi:10.1371/ journal.pone. 0094508

16. Kim JK, Diehl JA. Nuclear cyclin D1: an oncogenic driver in human cancer. J Cell Physiol. 2009;220(2):292-296. doi:10.1002/jcp.21791

17. Al-Kuraya K, Schraml P, Torhorst J, et al. Prognostic relevance of gene amplifications and coamplifications in breast cancer. Cancer Res. 2004;64(23):8534-8540. doi:10.1158/0008-5472.CAN-04-1945

18. Li Z, Cui J, Yu Q, Wu X, Pan A, Li L. Evaluation of CCND1 amplification and CyclinD1 expression: diffuse and strong staining of CyclinD1 could have same predictive roles as CCND1 amplification in ER positive breast cancers. Am J Transl Res. 2016;8(1):142.

19. Burandt E, Grünert M, Lebeau A, et al. Cyclin D1 gene amplification is highly homogeneous in breast cancer. Breast Cancer. 2016;23 (1):111-119. doi:10.1007/s12282-014-0538-y 
20. Elsheikh S, Green AR, Aleskandarany MA, et al. CCND1 amplification and cyclin D1 expression in breast cancer and their relation with proteomic subgroups and patient outcome. Breast Cancer Res Treat. 2008;109(2):325-335. doi:10.1007/s10549-007-9659-8

21. Ahlin C, Lundgren C, Embretsén-Varro E, Jirström K, Blomqvist C, Fjällskog M-L. High expression of cyclin D1 is associated to high proliferation rate and increased risk of mortality in women with ER-positive but not in ER-negative breast cancers. Breast Cancer Res Treat. 2017;164(3):667-678. doi:10.1007/s10549-017-4294-5

22. Mylona E, Tzelepis K, Theohari I, Giannopoulou I, Papadimitriou C, Nakopoulou L. Cyclin D1 in invasive breast carcinoma: favourable prognostic significance in unselected patients and within subgroups with an aggressive phenotype. Histopathology. 2013;62(3):472-480. doi: $10.1111 /$ his. 12013

23. Peurala E, Koivunen P, Haapasaari K-M, Bloigu R, JukkolaVuorinen A. The prognostic significance and value of cyclin D1, CDK4 and p16 in human breast cancer. Breast Cancer Res. 2013;15(1):1-10. doi:10.1186/bcr3376

24. Rudas M, Lehnert M, Huynh A, et al. Cyclin D1 expression in breast cancer patients receiving adjuvant tamoxifen-based therapy. Clin Cancer Res. 2008;14(6):1767-1774. doi:10.1158/1078-0432.CCR$07-4122$

25. Guo -L-L, Gao P, Wu Y-G, et al. Alteration of cyclin D1 in Chinese patients with breast carcinoma and its correlation with $\mathrm{Ki}-67, \mathrm{pRb}$, and p53. Arch Med Res. 2007;38(8):846-852. doi:10.1016/j. arcmed.2007.06.004

26. Lin H, Huang J-F, Qiu J-R, et al. Significantly upregulated TACSTD2 and cyclin D1 correlate with poor prognosis of invasive ductal breast cancer. Exp Mol Pathol. 2013;94(1):73-78. doi:10.1016/j. yexmp.2012.08.004

27. Hwang TS, Han HS, Hong YC, Lee HJ, Paik NS. Prognostic value of combined analysis of cyclin D1 and estrogen receptor status in breast cancer patients. Pathol Int. 2003;53(2):74-80. doi:10.1046/j.14401827.2003.01441.x

28. Lundgren K, Brown M, Pineda S, et al. Effects of cyclin D 1 gene amplification and protein expression on time to recurrence in postmenopausal breast cancer patients treated with anastrozole or tamoxifen: a TransATAC study. Breast Cancer Res. 2012;14(2):R57. doi:10.1186/bcr3161

29. Bavi P, Jehan Z, Atizado V, et al. Prevalence of fragile histidine triad expression in tumors from Saudi Arabia: a tissue microarray analysis. Cancer Epidemiol Biomarkers Prev. 2006;15(9):1708-1718. doi:10.1158/1055-9965.EPI-05-0972

30. Pratheeshkumar P, Divya SP, Parvathareddy SK, et al. FoxM1 and $\beta$ catenin predicts aggressiveness in Middle Eastern ovarian cancer and their co-targeting impairs the growth of ovarian cancer cells. Oncotarget. 2018;9(3):3590. doi:10.18632/oncotarget.23338

31. Camp RL, Dolled-Filhart M, Rimm DL. X-tile: a new bio-informatics tool for biomarker assessment and outcome-based cut-point optimization. Clin Cancer Res. 2004;10(21):7252-7259. doi:10.1158/1078-0432.CCR-04-0713
32. Gavressea T, Kalogeras KT, Koliou G-A, et al. The prognostic value of the immunohistochemical expression of phosphorylated RB and p16 proteins in association with cyclin D1 and the p53 pathway in a large cohort of patients with breast cancer treated with taxane-based adjuvant chemotherapy. Anticancer Res. 2017;37(6):2947-2957. doi:10.21873/anticanres. 11648

33. Siraj AK, Beg S, Jehan Z, et al. ALK alteration is a frequent event in aggressive breast cancers. Breast Cancer Res. 2015;17(1):1-12. doi:10.1186/s13058-015-0610-3

34. Sutherland RL, Musgrove EA. Cyclin D1 and mammary carcinoma: new insights from transgenic mouse models. Breast Cancer Res. 2001;4(1):14. doi:10.1186/bcr411

35. Eeckhoute J, Carroll JS, Geistlinger TR, Torres-Arzayus MI, Brown M. A cell-type-specific transcriptional network required for estrogen regulation of cyclin D1 and cell cycle progression in breast cancer. Genes Dev. 2006;20(18):2513-2526. doi:10.1101/ gad. 1446006

36. Chung J, Noh H, Park KH, Choi E, Han A. Longer survival in patients with breast cancer with cyclin $\mathrm{d} 1$ over-expression after tumor recurrence: longer, but occupied with disease. $J$ Breast Cancer. 2014;17(1):47-53. doi:10.4048/jbc.2014.17.1.47

37. Telles E, Seto E. Modulation of cell cycle regulators by HDACs. Front Biosci. 2012;4:831. doi:10.2741/s303

38. Zhang HS, Gavin M, Dahiya A, et al. Exit from G1 and S phase of the cell cycle is regulated by repressor complexes containing HDAC-Rb-hSWI/SNF and Rb-hSWI/SNF. Cell. 2000;101(1):79-89. doi:10.1016/S0092-8674(00)80625-X

39. Xu X-L, Chen S-Z, Chen W, et al. The impact of cyclin D1 overexpression on the prognosis of ER-positive breast cancers: a meta-analysis. Breast Cancer Res Treat. 2013;139(2):329-339. doi:10.1007/s10549-013-2563-5

40. Aftab A, Khan R, Shah W, et al. Computational analysis of cyclin D1 gene SNPs and association with breast cancer. Biosci Rep. 2021;41 (1). doi:10.1042/BSR20202269

41. Yan G, Dai M, Zhang C, et al. TGF $\beta /$ cyclin D1/Smad-mediated inhibition of BMP4 promotes breast cancer stem cell self-renewal activity. Oncogenesis. 2021;10(3):1-14. doi:10.1038/s41389-02100310-5

42. Beca F, Pereira M, Cameselle-Teijeiro JF, Martins D, Schmitt F. Altered PPP2R2A and cyclin D1 expression defines a subgroup of aggressive luminal-like breast cancer. BMC Cancer. 2015;15(1):285. doi:10.1186/s12885-015-1266-1

43. Topacio BR, Zatulovskiy E, Cristea S, et al. Cyclin D-Cdk4, 6 drives cell-cycle progression via the retinoblastoma protein's C-terminal helix. Mol Cell. 2019;74(4):758-70. e4. doi:10.1016/j. molcel.2019.03.020

44. Narasimha AM, Kaulich M, Shapiro GS, Choi YJ, Sicinski P, Dowdy SF. Cyclin D activates the Rb tumor suppressor by mono-phosphorylation. Elife. 2014;3:e2872. doi:10.7554/ eLife. 02872
OncoTargets and Therapy

\section{Publish your work in this journal}

OncoTargets and Therapy is an international, peer-reviewed, open access journal focusing on the pathological basis of all cancers, potential targets for therapy and treatment protocols employed to improve the management of cancer patients. The journal also focuses on the impact of management programs and new therapeutic agents and protocols on patient perspectives such as quality of life, adherence and satisfaction. The manuscript management system is completely online and includes a very quick and fair peer-review system, which is all easy to use. Visit http://www.dovepress.com/ testimonials.php to read real quotes from published authors. 